\title{
Transformation of Islamic Higher Education Institutions in Facing the Era of Industrial Revolution 4.0
}

Hainnur Aqma Rahim, Salimah Yahaya, Amirah Hazimah Borhanordin, Norlinda Tendot Abu Bakar

To Link this Article: http://dx.doi.org/10.6007/IJARBSS/v11-i2/8800

DOI:10.6007/IJARBSS/v11-i2/8800

Received: 18 December 2020, Revised: 17 January 2021, Accepted: 30 January 2021

Published Online: 22 February 2021

In-Text Citation: (Rahim et al., 2021)

To Cite this Article: Rahim, H. A., Yahaya, S., Borhanordin, A. H., \& Abu Bakar, N. T. (2021). Transformation of Islamic Higher Education Institutions in Facing the Era of Industrial Revolution 4.0. International Journal of Academic Research in Business and Social Sciences, 11(2), 311-319.

Copyright: (c) 2021 The Author(s)

Published by Human Resource Management Academic Research Society (www.hrmars.com)

This article is published under the Creative Commons Attribution (CC BY 4.0) license. Anyone may reproduce, distribute, translate and create derivative works of this article (for both commercial and non-commercial purposes), subject to full attribution to the original publication and authors. The full terms of this license may be seen at: http://creativecommons.org/licences/by/4.0/legalcode

Vol. 11, No. 2, 2021, Pg. 311 - 319

Full Terms \& Conditions of access and use can be found at http://hrmars.com/index.php/pages/detail/publication-ethics 


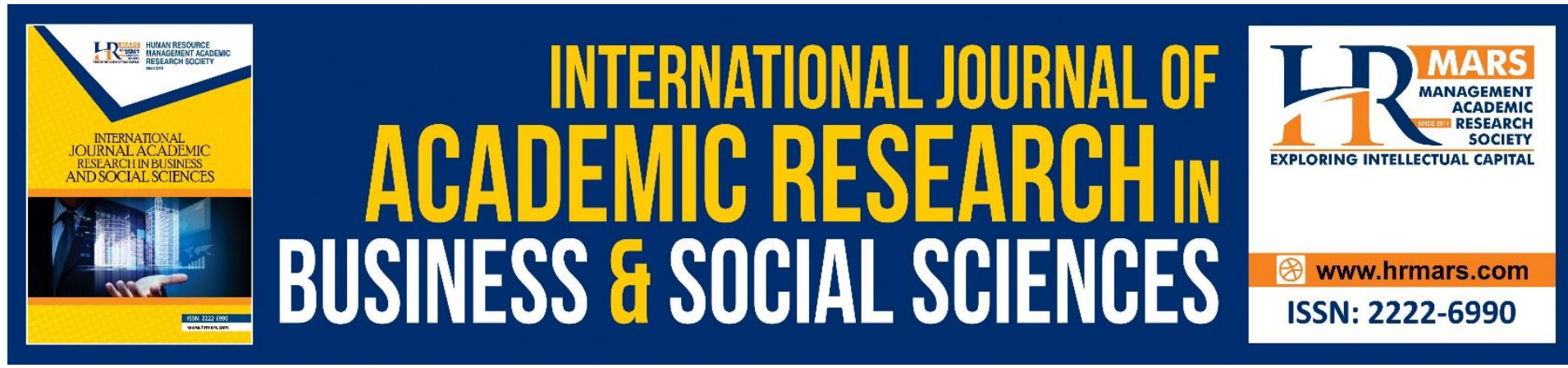

\title{
Transformation of Islamic Higher Education Institutions in Facing the Era of Industrial Revolution 4.0
}

\author{
Hainnur Aqma Rahim
}

Faculty of Business and Management, Center for Islamic Philanthropy \& Social Finance

(CIPSF), Universiti Teknologi MARA Cawangan Melaka

Email: hainnuraqma@uitm.edu.my

\section{Salimah Yahaya}

Academy of Contemporary Islamic Studies, Universiti Teknologi MARA Cawangan

Terengganu, Sura Hujung, 23000 Dungun, Terengganu, MALAYSIA

Email: sal_hasa@yahoo.com

\section{Amirah Hazimah Borhanordin}

Faculty of Business and Management, Universiti Teknologi MARA Cawangan Melaka,

110 Off Jalan Hang Tuah, 75300 Melaka, MALAYSIA

Email: amirahhazimah@uitm.edu.my

\section{Norlinda Tendot Abu Bakar}

Faculty of Business and Management, Universiti Teknologi MARA Cawangan Melaka, Km 26 Jalan Lendu, 78000 Alor Gajah, Melaka, MALAYSIA

Email: norlindatab@uitm.edu.my

\begin{abstract}
The Fourth Industrial Revolution (IR 4.0) based on digital economy is driving various transformations in all fields, including the education system by focusing not only on technological changes but also human changes to get closer to their Creator. Despite the rapid pursuit of IR 4.0, the education system is still in line with the main objective which is to produce moral human beings. Thus, this article presents three main purposes; 1 ) to identify Education 4.0 according to the Quran, education, and IR 4.0;2) to identify the challenges faced in the Education 4.0 implementation; and 3) to propose a competitive Education 4.0. This study employed a qualitative research methodology through data collection from several previous works. The findings of this study revealed that the incorporation of IR 4.0 in education not only creates employment opportunities in various fields but also simultaneously produces workforce with high morale, especially in universities to produce moral graduates.
\end{abstract}

Keywords: Higher Education, Transformation, IR 4.0, Institution. 


\section{Introduction}

The rise of a digital industrial technology, known as an Industrial Revolution 4.0 (IR 4.0), is a transformation that faciliates data collection and analysis across machines to enable faster, more flexible, and more efficient processes in producing high quality goods at lower costs. This manufacturing revolution will increase productivity and economic shifts, foster industrial growth, and change the workforce profile which in turn changes the competitiveness of a company and sector. The IR 4.0 is changing the current world economy from a resource-based conventional economy to a digital economy depending on the industrial technology. The presence of IR 4.0 emphasizing the development of virtual reality technology with less use of manpower certainly affects many aspects of life (Sabri, 2018). Groups of highly skilled and efficient workers are needed to accommodate robots and other automation systems to speed up production and productivity processes (Hameed, 2018).

\section{Islamic Higher Education}

Education is a continuous process in educating and shaping people to become moral human beings in this world and the hereafter (Ahmad, 1997). From an Islamic perspective, education can be defined as a process of educating and training the human mind, physically and spiritually based on Islamic values of Quran and Sunnah so that humans will devote themselves to Allah SWT. The above definition clearly shows that Islamic education is holistic, integrated, and has a balanced paradigm. Apart from emphasizing intellectual and physical elements, Islamic education also offers spiritual components for a prosperous and content life in this world and hereafter (Mujani, 2012). The goal of Islamic education is to develop and shape humans as servants and caliphs of Allah with knowledge, faith, taqwa, good deeds, and traits based on the Quran and al-Sunnah as well as enable them to contribute towards developing the nation and ummah.

The Center for Curriculum Development (2005) developed the philosophy of Islamic education as follows: "Islamic education is a continuous effort to convey knowledge, skills, and appreciation of Islam based on the Quran and Sunnah in shaping attitudes, skills, personalities, and purpose of life as a servant of God with responsibility of developing oneself, society, environment, and nation towards achieving virtue in this world and the hereafter".

Thus, religious education is not merely lecturing the subject to deliver its values but is actually a comprehensive learning to shape students' attitudes in theory and practice (Halstead, 2004).

\section{Industrial Revolution $\mathbf{4 . 0}$}

What is Industrial Revolution 4.0? It is a change of work that focuses on the patterns of digital economy, artificial intelligence, big data, and robotics amongst others. These changes are known as innovations that disrupt current world phenomena. In this era, the speed and use of internet technology can lead anyone to be a winner.

Shwab (2016) provided an example to help understand how the industrial revolution changes over time. During IR 1.0, water and steam were used for production management, while IR 2.0 presented the use of electrical power for mass production. For IR 3.0, electronics and information technology were used to automate production. 


\section{Quran, Education and Industrial Revolution 4.0}

Education 4.0 is a response to the needs of IR 4.0 where human and technological changes are aligned to allow for new possibilities. This requires more interdisciplinary teaching and research as some features of the innovations. Is Education 4.0 more efficient and effective? The success of science in revealing the secrets of Allah SWT is supported by the increasingly sophisticated technology. Science and technology research in Islam should lead us to contemplation and provide awareness for human beings to better understand their Creator. As the word of Allah SWT states:

"Indeed, in the creation of the heavens and the earth; the alternation of the day and the night; the ships that sail the sea for the benefit of humanity; the rain sent down by Allah from the skies, reviving the earth after its death; the scattering of all kinds of creatures throughout; the shifting of the winds; and the clouds drifting between the heavens and the earth - ' in all of this ${ }^{\urcorner}$are surely signs for people of understanding.

(Surah al-Baqarah: 164).

Despite the change of eras, Islam remains consistent and suitable for every period. The Quran is a relevant guide and can be used at any time without borders. There has never been a change in the verses of the Quran, and modern science has succeeded in revealing the secrets of Allah SWT contained in His book.

There are nine trends related to Education 4.0 (Fisk, 2017). First, learning can be carried out anywhere using e-learning tools for distance and self-paced learning for theoritical classes, while interactive learning is performed in the classroom. Second, student learning is conducted individually, where difficult tasks are given to students only after a certain level of mastery is achieved. At this level, a support group is needed to promote positive learning and increase students' confidence in their own academic abilities. Third, students have the option to determine their learning methods. Fourth, students will be exposed to many learning projects through the use of knowledge and skills in completing some short-term projects. By engaging in projects, they will collaborate and manage their time well. Fifth, students will be exposed to field-based learning such as industrial training, coaching projects, and collaboration projects. Sixth, students will be exposed to data interpretation through theoretical understanding and reasoning skills to draw conclusions based on logic and trends from a given data set. Seventh, students will be assessed based on their level of knowledge during the learning process and field projects. Eighth, student opinions will be considered in designing and updating the curriculum. Their input will help the development of the university curriculum to maintain the latest and quality curriculum framework. Finally, students are subjected to independent learning guided by instructors or facilitators through their learning process.

The nine trends in Education 4.0 by Fisk (2017) explains the shift of key learning responsibilities from educators to students. Educators need to play their part to support the transition and should not consider it as a threat to conventional teaching.

\section{Education in Malaysia}

The implementation of e-learning in the Malaysian education curriculum today is also seen to be beneficial to the Gen $Z$ and Alpha. The media that initially started from the transfer of 
information through radio has dramatically expanded to its digital counterpart, giving impact and creating public awareness that communication methods and knowledge distribution are no longer just through whiteboard and chalk as in the past.

According to Amin and Norazah (2013), lectures in lecture rooms are no longer conventional for university graduates to be in line with current creative and innovative technology by applying digital technology. Therefore, educators should take steps to identify the types of technologies that are able to connect the understanding of the new generation to that of the older generation. This is due to the availability of tools such as computers, smartphones, and software that are easy to use when studying either inside or outside of the classroom.

One of the government's efforts to increase innovation activities and programs in education is to develop the Education Development Master Plan (EDMP). The role of education has been outlined as the success of the EDMP mission to enhance the country's knowledge and innovation capacity as well as to develop the first class.

\section{Role of Educators}

The teaching staff in Islamic educational institutions should not only play their role as Murabbi and Muaddib but also as Mu'allim, Students are not only equipped with knowledge and skills but also good religious and moral strength. Thus, educators should possess spiritual strength with the help and support from the community as the foundation of human development. Therefore, Islam emphasizes self-esteem and integrity including 'aqidah, ibadah, and akhlaq to produce pious people (Asmawati \& Aderi, 2016; Amzar \& Noorsafuan, 2017).

Teaching and learning innovations are important features to be cultivated among educators because it is part of their main task (Halim, 2006; Azmi \& Halim, 2007). It is undeniable that education plays an important role in determining the future of society and nation. The next generation will highly depend on the education patterns provided.

\section{1st Century Learning Skills}

Fisk (2017) explains that new learning vision encourages students to discover not only skills and knowledge but to identify resources for skills and knowledge learning. There are seven soft-skills, namely communication, critical thinking, problem solving, teamwork, lifelong learning, entrepreneurial, ethical and moral roles, professionalism, and leadership skills (Nikitina \& Furuoka, 2012). Based on the World Economic Forum (2016), soft skills in IR 4.0 involve 10 skills, such as complex problem solving, critical thinking, creativity, human management, relationships with others, emotional intelligence, judgment and decision making, service orientation, consultation, and cognitive flexibility skills.

Cotet et al. (2017) list the dimensions of soft skills required in the IR 4.0 which are interpersonal, personal pledges, respect, self-strength, empathy, desire, perfection, selfdiscipline, intellectual curiosity, liberalism, freedom, and creativity skills. KPM (2012) focuses on five main principles consisting of critical thinking, problem solving, communication, cooperation, and creativity. he success of the 21st learning approach depends on the intelligence of teachers as professionals who can integrate practical knowledge in classroom concepts and teaching methods (PdPc) (Arbaa et al., 2017). 
A study by Anuar and Zakaria (2015) found that students in the education field at UiTM were able to use technology easily and have the necessary technical skills in educational learning. A majority of students agreed that they have adequate knowledge and are able to seek various ways to use technology to develop an understanding of education.

\section{Challenges and Obstacles in Implementation}

Industrial development is a challenge for educational institutions, especially universities, in providing competent graduates. It has started since the beginning of the first industrial revolution, where human beings were no longer needed for their energy and abilities. In addition, technological advances have also resulted in the retrenchment of employees from their positions as their roles have been replaced by machines. In fact, future demands will be greatly challenging for employees with lack of skills, innovation, and ability to operate various technological devices in the industry. Therefore, university graduates need to obtain better abilities than high school graduates.

To be able to compete in highly competitive industries, human resources need to have skills, innovation, a mastery in technology and information, and survivability (Wijaya et al. 2016). Therefore, the role of higher education is significant in providing the younger generation with good vision and knowledge in the form of theory and practice, as well as various skills and soft skills upgrades so that the students will be prepared to make the best of the IR 4.0.

Moreover, the aspect of educators' knowledge is also important as not all teachers have the skills and the exposure to technological tools to implement innovative teaching in the classroom. A study conducted by llias and Ladin (2018) found that the knowledge of the teaching staff on IR 4.0 was still at a moderate level. Changes in the context of continuous learning and information management through the evolution of the internet have challenged the concepts and theories of traditional education, particularly on the notions of classrooms and teaching methods (PdPc). The impact of technology will change social relationships and future generations. As software programs are enhanced, technology-based learning should also be mastered.

Furthermore, the IR 4.0 also poses more challenges related to moral establishment and character of the younger generation. From an observation study conducted in a university environment, Raka (2008) postulated that students were eager to use their study period not only to enhance their knowledge but also to enhance their own identities. This indicated that universities have a very complex function as educational institutions. Higher education will generally shape the character of students by guiding local wisdom and social culture of the local community. Religious education is also an essential element in shaping the qualities of students. The importance of teaching morals and shaping the character of students is to motivate them to frequently act according to the norms and teachings of religion in the era of IR 4.0 .

A study conducted by Robles (2012) found that some weaknesses in the integration of soft skills in the classroom were due to the workload of teachers, excessive syllabi, and unclear approaches in teaching soft skills. The teaching of soft skills is more challenging compared to the teaching of skills in academic subjects or hard skills. The application of soft skills can 
increase involvement in learning and cultivate communication, critical thinking, and creativity skills (KPM, 2017).

The latest generation Z (1998-2009); Alpha (2015) have unique and different characters which requires an in-depth understanding. According to Tapscott (2015), these generations are born surrounded by extensive use of the internet and the way they obtain and understand any knowledge including the world is by navigating through a particular issue.

Smith and Anderson (2014) stated that $48 \%$ of experts have predicted that robots and digital agents will lead to unemployment by 2025 , while the remaining $52 \%$ perceived that technology will not replace jobs but without up-to-date knowledge and skills will trigger the inability to compete.

\section{Views and Recommendations}

Transformation and innovation in teaching and education in Malaysia can be assessed through the current level of learning and development of students. Changes in student learning can be seen through a holistic approach that emphasizes intellectual, spiritual, emotional, and physical values in line with a strong national identity (Malaysia Education Development Plan, 2012).

In the Malaysian Education Development Plan (MEDP) 2013-2025, educators are the drivers in the educational development by further strengthening the nation's civilization through the invention of dynamic human module. Through quality and established education, we are able to produce world-class students with critical thinking skills of the 21st century in step with the National Education Philosophy (Thirugnana, 2018).

The goals that have been outlined in the MEDP 2013-2025 are as follows: 1) to fully develop the potentials of individuals in terms of physical, emotional, spiritual, and intellectual aspects; 2) to enhance students' creativity, innovation, and culture; 3) to involve science and technology as well as lifelong learning; 4) to provide more efficient, effective, and world-class education system; 5) to make Malaysia a center of educational excellence; and 6) to improve the quality of the Malaysian education system internationally.

\section{Conclusion}

Industrial revolutions from 1.0 until 4.0 provide opportunities for employment to those with the necessary skills in various fields. The employment world is seeking employees equipped not only with skills in general science but also good moral qualities. Therefore, it is a necessity for Islamic higher learning institutions to provide graduates with competency, professionalism, and superior moral characteristics who will meet the demands for various professional fields.

\section{References}

Tamuri, A. H. (2006). Model Guru Pendidikan Islam: Konsep 5 Mim. Kertas Kerja Seminar Amalan Pengajaran Guru Pendidikan Islam. Bilik Senat, Bangunan Canselori, Universiti Kebangsaan Malaysia.

Salleh, A. M. (1997). Pendidikan Islam: Falsafah, Sejarah dan Kaedah Pengajaran dan Pembelajaran. Selangor: Penerbit Fajar Bakti. 
Beekun, R. (1997). Islamic Business Ethics. IIIT, Herndon, Virginia, U.S.A.

Halstead, M. (2004). An Islamic concept of education. Comparative education, 40(4), 517-529.

Hasingsih, S. (2008). Peran Strategis Pesantren, Madrasah, dan Sekolah Islam di Indonesia. ElTarbawi-Jurnal Pendidikan Islam, Vol. 1(1).

Ladin, C. A. (2015). Pentaksiran Berasaskan Sekolah Pendidikan Seni Visual sekolah Menengah. Tesis Doktor Falsafah. UPSI.

Cotet, G. B., Balgiu, B. A., \& Zaleschi, C. (2017). The assessment procedure for the soft skills requested by industry 4.0. MATEC Web of Conference 121.

Tapscott, D. (2009). Grown up Digital: How the Net Generation is Changing Your World. USA: McGraw Hill.

Dunwill, E. (2016). 4 changes that will shape the classroom of the future: Making education fully technological. Accessed from https://elearningindustry.com/4-changes-willshape classroom-of-the-future-making-education-fully-technological.

Fisk, P. (2017). Education 4.0 ... the future of learning will be dramatically different, in school and throughout life. Retrieved from

http://www.thegeniusworks.com/2017/01/future education-young-everyone-taughttogether.

Ilias, K., \& Ladin, C. A. (2018). Pengetahuan dan kesediaan Revolusi Industri 4.0 dalam kalangan pelajar Institut Pendidikan Guru Kampus Ipoh. International Seminar on Education Issues (ISPEN).

Jasmi, K. A., \& Tamuri, A. H. (2007). Guru cemerlang dalam sekolah berkesan. Kertas Kerja Seminar.

Jasmi, K. A., \& Tamuri, A. H. (2007). Pendidikan Islam: Kaedah Pengajaran dan Pembelajaran. Pendidikan Kebangsaan Halatuju dan Masa Depan. Pendidikan Negara. Anjuran Fakulti Pendidikan, Universiti Malaya, Kuala Lumpur. 22-23 Ogos. Skudai, Johor Bahru: Penerbit UTM Press.

Kozinski, S. (2017). How generation $Z$ is shaping the change in education. Retrieved from https://www.forbes.com/sites/sievakozinsky/2017/07/24/how-generation-zisshaping-the change-in-education/\#304059746520

Sambanthan, M. T. (2018). Utusan Online, 17 Mei. http://www.utusan. com.my/rencana/utama/gurupemacu-transformasi-pendidikan1.674261\#ixzz5 Tg3FXzO0

Crindle, M. M. (2014). The ABC of XYZ understanding the global generations. New Zealand: McCrindle Research Pty Ltd.

Embi, M. A., \& Nordin, N. M. (2013). Mobile Learning: Malaysian Initiatives \& Research Findings. Putrajaya: Centre for Academic Advancement, Universiti Kebangsaan Malaysia \& Department of Higher Education, Ministry of Higher Education.

Nawawi, M. M., \& Noh, N. C. (2017). Teori Pengajaran dan pembelajaran Bahasa Arab di sekolah menengah agama di Malaysia. Islamiyyat 39(1): 85-87.

Mujani, W. K., Ibrahim, I. A., \& Safiai, M. H. (2012). Observatories in Islamic history. Advances innatural and applied sciences 6(8): 1370-1373.

Nikitina, L., \& Furuoku, F. (2012). Sharp Focus on soft skills: a case study of Malaysian University student's educational expectations. Education Res Policy Prac 1(11), 207-224.

Hameed, N. M. S. (2018). Elak jadi korban Industri 4.0. Utusan online http://www.utusan.com.my/rencana/utama/elak-jadikorbanindustri-4-0-

1.590945\#ixzz55 A7ZbbR 7 
Raka, I. I. D. G. (2008). Pembangunan Karakter dan Pembangunan Bangsa: Menengok Kembali Peran Perguruan Tinggi. Published Last Lecture on Majelis Guru Besar Institut Teknologi Bandung.

Robles, M. M. (2012). Executive perceptions of the top 10 soft skills needed in today's workplace. Business Communication Quarterly, 75(4), 453-465.

Arbaa, R., Jamil, H., \& Ahmad, M. Z. (2017). Model Bersepadu Penerapan Kemahiran Abad Ke21 dalam Pengajaran dan Pembelajaran. Jurnal Pendidikan Malaysia, 42(1), 1-11.

Anuar, R., \& Zakaria, W. W. Z. (2015). TPACK dalam Pendidikan Seni Visual: Satu Kajian Mengenai Kesediaan Pelajar Menggunakan EPembelajaran dalam Pembelajaran Pendidikan Seni Visual. Jurnal Seni dan Pendidikan Seni 3(3), 8-18.

Ahmad, S. (2018).https://news.utm.my/ms/2018/01/revolusi-industri-4-0-beri-pelbagai kesanpada-kehidupan.

Sharif, S. M. (2017). Utusan Online. http://m.utusan.com.my/rencana/ utama/memahamipeluangrevolusiperindustrian-1.558558

Shwab, K. (2016). The Fourth Industrial Revolution: what it means, how to respond. Accessed from https://www.weforum.org/agenda/2016/01/the-fourth-industrial-revolutionwhat-it-means-andhow-to-respond.

Smith, A., \& Anderson, J. (2014). Al, Robotics, and the Future of Jobs. Pew Research Center, 6.

Tapscott, D. (2015). The digital economy: Rethinking promise and peril in the age of networked intelligence. New York: McGraw-Hill Education.UNDP, Human Development Report 2016, 2017.

Wijaya, E. Y., Sudjimat, D. A., \& Nyoto, A. (2016). Transformasi pendidikan abad 21 sebagai tuntutan pengembangan sumber daya manusia di era global. In Prosiding Seminar Nasional Pendidikan Matematika (Vol. 1, No. 26, pp. 263-278).

World Economic Forum. (2016). "The Future of Jobs Employment, Skills and Workforce Strategy for the Fourth Industrial Revolution," Growth Strategies, pp. 2-3. 